\title{
Recording Data Labour With Documentation Midwifery Partograph Based on Word Electric Browser (WEB)
}

\author{
Juwita $^{1}$, Mardiana Ahmad ${ }^{1}$, Syafruddin Syarif ${ }^{1,2}$, Nasruddin A.Mappaware ${ }^{1,3}$, \\ Prihantono ${ }^{1,4}$ \& Burhanuddin Bahar ${ }^{1,5}$ \\ ${ }^{1}$ Postgraduate Program, Departement of Midwifery, Hasanuddin University, Makassar, South Sulawesi, Indonesia \\ ${ }^{2}$ Departement of Electrical Engineering, Hasanuddin University, Makassar, South Sulawesi, Indonesia \\ ${ }^{3}$ Medical Faculty, Universitas Muslim Indonesia, Makassar, South Sulawesi, Indonesia \\ ${ }^{4}$ Departement of Surgery, Faculty of Medicine, Hasanuddin University, Makassar, South Sulawesi, Indonesia \\ ${ }^{5}$ Department of Nutrition, Faculty of Public Health, Hasanuddin University, Makassar, South Sulawesi, Indonesia \\ Correspondence: Juwita, Postgraduate Program, Department of Midwifery, Hasanuddin University, Makassar, \\ South Sulawesi 90245, Indonesia: Tel: 62-853-4230-2358. E-mail: juwitarahman8@gmail.com
}

Received: March 23, 2019 Accepted: April 24, 2019 Online Published: April 30, 2019

doi:10.5539/gjhs.v11n5p149 URL: https://doi.org/10.5539/gjhs.v11n5p149

\begin{abstract}
Introduction: Midwifery documentation is a proof of recording and reporting possessed by midwives in carrying out records in documenting care provided.

Material and Methods: The research method used was the comparative study with the comparative descriptive design. The total subjects of 30 mothers in labor were chosen using the purposive sampling technique. The subjects were divided into two groups: 15 of the mothers used the conventional midwifery documentation and 15 of them used the WEB-based. The data were analyzed using the univariate analysis in order to look at the median value, and the bivariate analysis with Mann-Whitney test.

Results: The study results indicated the the highest frequency was found in the WEB-based partograph, namely he filling speed was $26(86.7 \%)$, the highest frequency of partograph filling truth was that of the WEB-based partograph $=25(83.3 \%)$, while the highest Relevance of the data frequency was found in the WEB-based partograph with the data Relevance $=27(90 \%)$. The result of the statistical test had the $\mathrm{p}$ value of $0.000,0.000$, and $0.000(<\alpha=0.05)$ meaning there was a difference of the WEB-based midwifery documentation compared to the conventional midwifery documentation.
\end{abstract}

Conclusion: Thus it can be concluded that web-based midwifery documentation is more effective than conventional midwifery documentation. There are differences in the aspects of ease, speed, security and relevance of data to recording labor history data so that it needs to be applied in documenting midwifery care.

Keywords: WEB-based midwifery documentation, conventional

\section{Introduction}

Midwifery documentation is a proof of recording and reporting possessed by midwives in carrying out records in documenting care provided. According to WHO, the use of partographs will reduce long labor $6.4 \%$ to $3.4 \%$ of cases of caesarea $44 \%$ to $21 \%$. Some of the things that affect the low recording in partographs are the level of knowledge of midwives about partographs which is not very influential in monitoring labor, recording documents and reporting partographs, making clinical decisions and planning future actions. During this time reporting and documentation by midwives was based on recording in partographs on paper, however, based on several studies said that there were still many midwives who did not complete the data in the partograph well and systematically, therefore a recording system, faster reporting and documentation of partographs in a computer and web-based data storage to facilitate the work of midwives in storing and re-accessing current and past labor history so as to prevent the accumulation of partograph files (Baillie, Chadwick, Mann, \& Brooke-Read, 2013; Kitila, Gmariam, Molla, \& Nemera, 2014; Asibong et al., 2014; Okokon, Oku, Agan, Asibong, Essien, \& Monjok, 2014; Anita, 2016; Andrianto, 2017; Balikuddembe, Tumwesigye, Wakholi, \& Tylleskär, 2017; Bedwell, Levin, Pett, \& Lavender, 
2017; Erawantini et al., 2017; Mandiwa \& Zamawe, 2017; Fatusi, Makinde, Adeyemi, Orji, \& Onwudiegwu, 2008; Nugroho, Fitriasih, \& Widada, 2015; Ramdhani, Isnanto, \& Windasari, 2015; Sovia \& Febio, 2011; Sundari, 2016; Widyaningsih \& Astutingsih, 2016; Fahdhy \& Chongsuvivatwong, 2005; Yisma, Dessalegn, Astatkie, \& Fesseha, 2013a, 2013b; Baillie et al., 2013; Gans-Lartey, O'Brien, Gyekye, \& Schopflocher, 2013; Ollerhead and Osrin, 2014; Aliona Masika, Peter Katongole, \& Govule, 2015; Mathews, Rajaratnam, George, \& Mathai, 2007; JNPK-KR, 2012; Bailey, Wilson, \& Yoong, 2015; Opoku \& Nguah, 2015; Fatouh, 2015; Vidyashri \& Nagarathna, 2015; Nugroho, Fitriasih, \& Widada, 2015; Byukusenge et al., 2016; Kwast, 1994; Yisma et al., 2013a; Opoku \& Nguah, 2015; Sinaga, 2016; Susilowati \& Sulistiyaningsih, 2011; Tayade \& Jadhao, 2012; WHO, 2011; 2014).

The study obtained a total of 1070 partograph reviewed, $58.6 \%$ of the partograph had no record of maternal blood pressure, $65.3 \%$ had no documentation of temperature, $25.4 \%$ Molding was not recorded, $14.9 \%$ of fetal heart rate was not recorded and $12.0 \%$ of the decrease in fetal head is not recorded so that there are still many shortcomings in systematic recording and documentation (Balikuddembe et al., 2017; Mandiwa \& Zamawe, 2017; Nurmiyati, 2011).

Based on the description above, the author was motivated to develop a web-based partograph midwifery documentation database research system. This is intended to streamline the process of recording, reporting and documenting partograph in aspects of speed, convenience, security, and convenience by using the Subjective, Objective, Analysis and Management (SOAP) methods. And in accessing again and seeing the recording of labor history and actions taken by the midwife so that it can accelerate clinical decisions, plan actions taken and streamline reporting, documentation in midwifery and prevent the accumulation of partograph files (Bhatt, Kar, Shashank, \& Somarajan, 2004; Chaturvedi et al., 2015; Erawantini et al., 2017; Hadi et al., 2017; Hasan, Hossain, Arafat, Khan, Ahmed, \& Shabnam, 2017; Underwood, Sterling, \& Bennett, 2012; Schweers, Khalid, Underwood, Bishnoi, \& Chhugani, 2016; Jennifer, 2012; Souza et al., 2015; Lavender, Hart, \& Smyth, 2013; Mathibe-Neke, Lebeko, \& Motupa, 2013; Kitila et al., 2014; Kamath, Nagarathna, \& Sharanya, 2015; Mandiwa \& Zamawe, 2017; Lew \& Ghassemzadeh, 2018; Nursing and Midwifery Council 2010a; 2010b; Sama et al., 2017; Seo et al., 2016; Sinha, S. Shrivastava, \& S. Shrivastava, 2016; Sudarti, 2011; Varney, 2008).

\section{Materials and Methods}

\subsection{Design of the Study and Sample Population}

The research design used was quasi-experimental using a treatment group on web-based partograph midwifery documentation and control groups in conventional partograph midwifery documentation. This research was conducted at the Bara-Barayya Health Center, Antang Community Health Center and Makassar City Health Office, Makassar, South Sulawesi, Indonesia from November 2018 to January 2019. The research tools here are hardware components and software used as tools in supporting research conducted, this tool will be used as a data processing tool and the making of the system to be designed. The research method used is a comparative study with a descriptive comparative design. The total subjects of 30 mothers in labor were selected using purposive sampling technique. Subjects were divided into two groups: 15 mothers of labor records using conventional midwifery documentation and 15 mothers of labor records using WEB-based midwifery documentation. Data were analyzed using univariate analysis to see the median value and bivariate analysis with the Mann-Whitney test. Sampling from the study population was carried out by purposive sampling, where populations that met the inclusion criteria were included as sample members. The number of subjects was 30 patient data, 30 labor patients were documented using conventional partograph midwifery documentation and web-based partograph midwifery documentation. Samples were divided into 2 groups of data, 15 patient data filled using conventional partograph (manual) and 15 patient data filled using computer-based partograph Further more, 30 mothers in the delivery process will be filled by 9 midwives in the delivery room of Antang Perumnas Health Center, 8 midwives in the delivery room of the Bara-Baraya Makassar Health Center and 1 midwife at the Makassar City Health Office will see partograph documentation as data reporting, 17 of these midwives will fill 30 data patients used conventional partograph midwifery documentation (manual) and patient data was filled using web-based partograph midwifery documentation. Midwives from the Publich Health Center who are used as subjects are categorized by age, length of work, training that has been attended. The results of the filling will be assessed using an observation sheet that contains a column of the number of speeds in seconds with measurements using a stopwatch, the correctness of filling with the standard midwifery documentation format reference, and the relevance of the appropriate data from the results of the examination and the results inputted on the website. The primary data obtained directly on the data source is when conducting interviews with midwives and maternity mothers, making observations on filling partograph documentation carried out by midwives about the progress of labor, care provided and results obtained. 


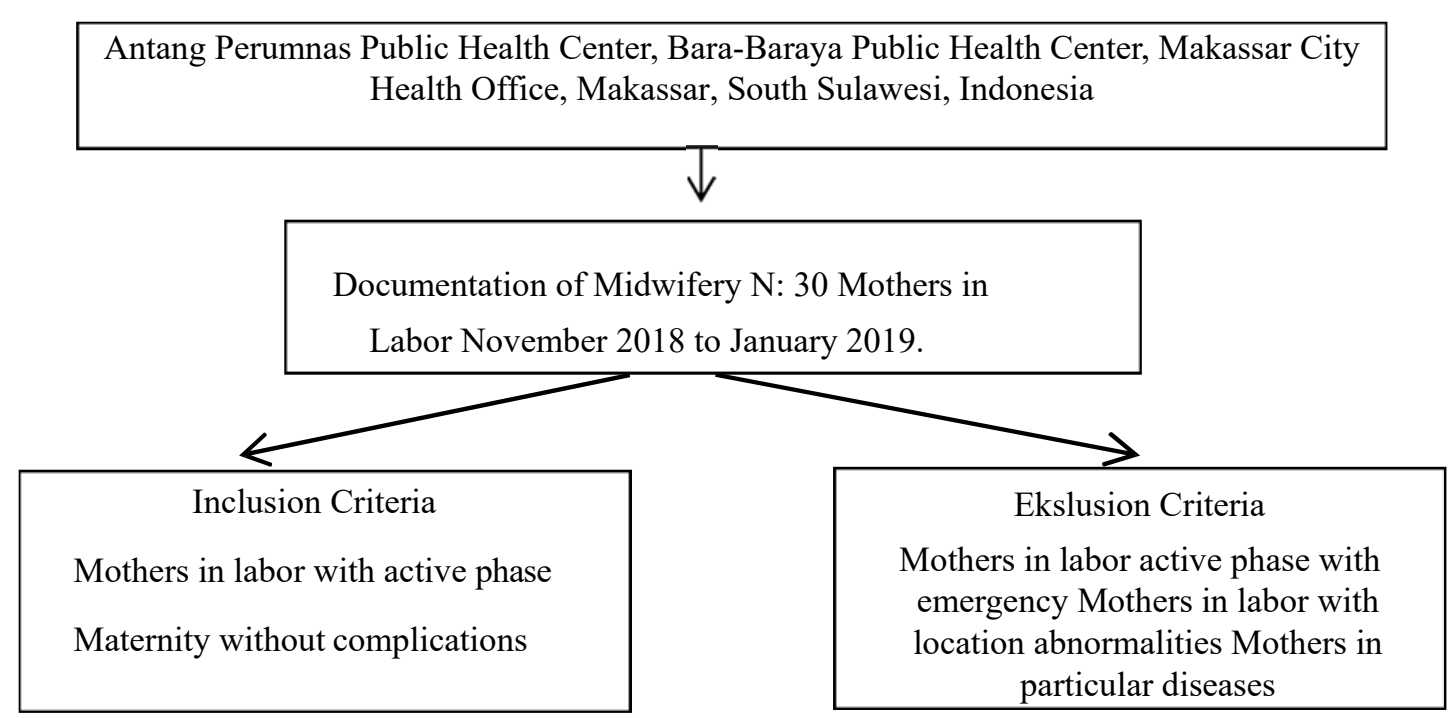

Ficture 1. The Flowchart of the Study

\subsection{Data Collection}

The primary data obtained directly on the data source is when observing the actions taken by the midwife and the results recorded, namely at the Antang Perumnas Health Center, Makassar Bara-Barayya Health Center and Makassar City Health Office Makassar, South Sulawesi, Indonesia. Secondary data obtained indirectly to support writing in this study through documents or records of medical records of mothers who have given birth at the research site, The total subjects of 30 mothers in labor mothers were chosen using the purposive sampling technique. The subjects were divided into two groups: 15 of the mothers used the conventional midwifery documentation and 15 of them used the WEB-based midwifery documentation namely at the Antang Perumnas Public Health Center, Makassar Bara-Barayya Public Health Center and Makassar City Health Office, South Sulawesi, Indonesia.

\subsection{Ethical Considerations}

This study received ethical clearance from the Research and Ethics Committee of Faculty of Medicine, Hasanuddin University and was registered in 972/h4.8.4.5.31/PP36-KOMETIK/2018. And protocol number: UH18100691.

\subsection{Data Management and Analysis}

Descriptive analyses were presented as mean \pm standard deviation and frequencies for categorical variables. Bivariate analyses were analyzed and processed using independent t-test in pairs, Mann-Whitney to determine the differences between all groups at 5\% level of significance. Spearman's correlation was used to determine further correlations. Data were analyzed using the Statistical Package for Social Science (SPSS) version 24 for Windows.

\section{Results}

Sampling from the study population was carried out by purposive sampling, where the population that met the inclusion criteria was included as sample members. The number of subjects was 30 patient data, 30 deliveries were documented using conventional partograph midwifery documentation and web-based partograph midwifery documentation. Samples are divided into 2 groups of data, 15 patient data filled using conventional partograph (manual) and 15 patient data filled using computer-based partograph.

\subsection{Univariate Analysis}

Midwifery Documentation Comparison From Time Speed Aspects, Truths Charging, Data Security and Data Relevance Midwifery Documentation Website-Based Partographs. 
Table 1. Characteritics of filling in website system partograph midwifery documentation and conventional partograph midwifery documentation from aspects of ease of filling, time speed, data security, data relevance

\begin{tabular}{lll} 
& \multicolumn{2}{l}{ Midwifery Documentation } \\
\cline { 2 - 3 } Characteristics & Website Based & Conventional \\
\cline { 2 - 3 } & $\mathrm{F} \%$ & $\mathrm{~F} \%$ \\
\hline Time Speed & $26(86.7)$ & \\
Hurry up & $4(13.3)$ & $30(100)$ \\
Long & & $9(30)$ \\
\hline Truth of Charging & $25(83.3)$ & $21(70)$ \\
Right & $5(16.7)$ & $9(30)$ \\
Not exactly & & $21(70)$ \\
\hline Data Relevance & $27(90)$ & 100 \\
Right & $3(10)$ & \\
Not right & 100 & \\
\hline Total & & \\
\hline
\end{tabular}

Source : Primary Data, Paired t test.

Table 2. Average scores for filling website-based partograph documentation and conventional partographs from the speed aspect of charging time

\begin{tabular}{llll}
\hline Characteristics & Mean & SD & Min - Maks \\
\hline Charging time & & & $19-24$ \\
Website-based partograph documentation & 21.7 & 1 & $29-34$ \\
Conventional Partographical Documentation & 31.1 & 1 & \\
\hline
\end{tabular}

Source: Primary Data, Paired t test.

\subsection{Bivariate Analysis}

Analysis of differences in website-based partograph midwifery documentation and conventional partograph midwifery documentation against.

Table 3. Differences in midwifery partographies of websites based on websites and midwifery documentation of conventional partographs on recording of childbirth history data

Test Statistics ${ }^{\mathrm{a}}$

\begin{tabular}{llll}
\hline & Truth Time & Speed Charging & Data Relevance \\
\hline Mann-Whitney U & 60.000 & 210.000 & 180.000 \\
Wilcoxon W & 525.000 & 675.000 & 645.000 \\
Z & -6.717 & -4.134 & -4.704 \\
Asymp. Sig. (2-tailed) & .000 & .000 & .000 \\
\hline
\end{tabular}

Source: Primary Data, ${ }^{\mathrm{a}}$ Mann-Withney Test.

\section{Discussion}

Table 1 The results obtained the speed of time needed for filling Website-based partograph and conventional partograph, the highest frequency was found on web-based partograph, namely fast charging 26 (86.7\%), while the 
truth of the highest frequency partograph filling was website-based partograph, 25 (83.3\%) . Data security obtained the highest frequency, namely on website-based partograph, which is $30(100 \%)$, while the highest frequency data relevance is website-based partograph with data relevance of $27(90 \%)$. The results of this study indicate that the use of website-based partograph midwifery documentation will make it easier for midwives to process the recording, reporting and recording of labor history data, website-based partograph midwifery documentation will minimize errors and have a good level of truth. This is in line with the research conducted by Heather et al., 2012, Heather et al., 2014 which found that the use of electronic partograph was more effective and efficient with the use of hardware and software as a documentation and recording of labor history that could be used as a tool to train labor health about how to use the correct partograph with limited human resources so that it has an impact on the completeness of partograph filling, reducing the error rate (Qureshi, Sekadde-Kigondu, \& Mutiso, 2010; Pirie, 2011; Ontario, 2013; Maureen D, et al., 2015; Muslihatun et al., 2013; Ollerhead \& Osrin, 2014; Sharma, Deka, \& Das, 2015).

Table 2 gaining from the speed of filling the website-based partograph midwifery documentation and conventional midwifery documentation, the average time required for filling in website-based partograph midwifery documentation was 21.7 minutes, with a standard deviation of \pm 1 second, while documentation of conventional partograph midwifery time needed to fill more that is 31.1 minutes with a standard deviation of \pm 1 second.

The results of research conducted by Yulianti et al. (2018) got the use of electronic partograms in recording and reporting partograph documentation with incoming data speeds of $82 \%$ with an error rate of $18 \%$, in the process of recording and reporting the time used for charging is relatively shorter 8.6 hours, so it can be concluded that the use of electronic partograms allows data to enter faster with a lower error rate than conventional partograms

Table 3 shows the analysis of data using Test, obtaining a p value of $0.000(<0.05)$ means that there are differences in website-based partograph midwifery documentation and conventional partograph midwifery documentation on recording delivery history data from aspects of filling filling truth, data security and data relevance (Sugiyono, 2014; Wildan dan Hidayat, 2009).

The statistical test results require an average time of 21.7 minutes, ease of filling is also seen in the correct level of charging that is true $83.3 \%$. The ease of filling will have an effect on the time needed to be shorter, the human resources needed are more simple and the quality of midwifery services is more optimal. This is in accordance with the research conducted stating that for facilitation aspects in the process of documenting midwifery and care provided, it gives information to officers on what has been recorded so that it makes it easier in the process of managing subsequent actions (Lavender, Hart, \& Smyth, 2013; Fatouh \& Ramadan, 2015; Ontario, C. of M. of 2013; Toemandoek, Wagey, \& Loho, 2015).

\section{Conclusion}

Website-based partograph midwifery documentation is better than conventional midwifery documentation seen from the aspect of a short time velocity of 21.7 minutes using web-based partograph midwifery documentation and obtaining a 31.1 minute filling time speed in using conventional partograph midwifery documentation, the correct aspect of filling with columns filled with complete, systematic and appropriate, and relevant data relevance because it is stored in digital form. A web-based partograph midwifery documentation database effectively re-accesses labor history records and actions that have been given.

\section{Acknowledgements}

The authors would like to express their special thanks to the Antang Perumnas Public Health Center, Bara-Baraya Public Health Center, Makassar City Health Office and staff for their support and assistance.

\section{Competing Interests Statement}

The authors declare that there are no competing or potential conflicts of interest.

\section{References}

Kitila, S. B., Gmariam, A., Molla, A., \& Nemera, G. (2014). Utilization of partograph during labour and birth outcomes at Jimma University. Journal of Pregnancy and Child Health, 1(101), 2. https://doi.org/10.4172/2376-127X.1000101

Fatusi, A. O., Makinde, O. N., Adeyemi, A. B., Orji, E. O., \& Onwudiegwu, U. (2008). Evaluation of health workers' training in use of the partogram. International Journal of Gynecology \& Obstetrics, 100(1), 41-44. https://doi.org/10.1016/j.ijgo.2007.07.020 
Ashish, K. C., Johan, W., Robert, B. C., Uwe, E., \& Mats, M. (2016). Inadequate Fetal Heart Rate Monitoring And Poor Use Of Partogram Associated With Intrapartum Stillbirth: A Case-Referent Study In Nepal. BMC Pregnancy and Childbirth. https://doi.org/10.1186/s12884-016-1034-5

Aliona Masika, M., Peter Katongole, S., \& Govule, P. (2015). Improving Partograph Documentation and Use by Health Workers of Bwera Hospital: A Process Improvement Research. International Journal of Nursing and Health Science. Retrieved from http://www.openscienceonline.com/journal/ijnhs

Andrianto, P. (2017). Web Web Based Health Service Information System at Publich Health Center. Proceedings of the National Computer and Informatics Seminar (SENASKI).

Anita, W. (2016). Learning Methods in Partographic Documentation Skills in Midwifery Care in Childbirth: Literature Review. Jurnal Endurance. htpps://doi.org/10.22216/jen.v1i3.1073

Asibong, U., Okokon, I. B., Agan, T. U., Oku, A., Opiah, M., Essien, E. J., \& Monjok, E. (2014). The use of the partograph in labor monitoring: A cross-sectional study among obstetric caregivers in General Hospital, Calabar, Cross River State, Nigeria. International journal of women's health, 6, 873. https://doi.org/10.2147/IJWH.S49188

Bailey, S., Wilson, G., \& Yoong, W. (2015). What factors affect documentation by midwives? A prospective study assessing relationship between length of shift, workload and quality of note keeping. Midwifery, 31(8), 787-792. https://doi.org/10.1016/j.midw.2015.04.001

Baillie, L., Chadwick, S., Mann, R., \& Brooke-Read, M. (2013). A survey of student nurses' and midwives' experiences of learning to use electronic health record systems in practice. Nurse Education in Practice, 13(5), 437-441. https://doi.org/10.1016/j.nepr.2012.10.003

Balikuddembe, M. S., Tumwesigye, N. M., Wakholi, P. K., \& Tylleskär, T. (2017). Computerized childbirth monitoring tools for health care providers managing labor: a scoping review. JMIR medical informatics, 5(2), e14. https://doi.org/10.2196/medinform.6959

Bedwell, C., Levin, K., Pett, C., \& Lavender, D. T. (2017). A realist review of the partograph: when and how does it work for labour monitoring? BMC pregnancy and childbirth, 17(1), 31. https://doi.org/10.1186/s12884-016-1213-4

Bhatt, B. M., Kar, G., Shashank, S., \& Somarajan, S. (2013, September). Designing interfaces for healthcare workers: a case study of the electronic partogram. In Proceedings of the 11th Asia Pacific Conference on Computer Human Interaction (pp. 187-191). ACM. https://doi.org/10.1145/2525194.2525268

Byukusenge, J. B., Adomako, E., Lukas, S., Mugarura, C., Umucyo, J., Mukagatare, S., ... \& Wong, R. (2016). Implementing a labor monitoring guideline and midwives responsibilities to increase the completion rate of partograph in Muhima Hospital, Rwanda. On the Horizon, 24(4), 335-340. https://doi.org/10.1108/OTH-07-2016-0036

Erawantini, F. et al. (2017). Design Input Data Determining Risk Factors for Early Type 2 Diabetes Mellitus Based on the Web. Health Journal, 5(1).

Fahdhy, M., \& Chongsuvivatwong, V. (2005) Evaluation of World Health Organization partograph implementation by midwives for maternity home birth in Medan, Indonesia. Midwifery. https://doi.org/10.1016/j.midw.2004.12.010

Fatouh, E., \& Ramadan, S. (2015). Effect of Using Paperless Partogram on the Management and Outcome of Labour and the Nurses' Opinion. Journal of Education and Practice, 6(8), 17-23. Retrieved from https://eric.ed.gov/?id=EJ1082718.

Gans-Lartey, F., O'Brien, B. A., Gyekye, F. O., \& Schopflocher, D. (2013). The relationship between the use of the partograph and birth outcomes at Korle-Bu teaching hospital. Midwifery, 29(5), 461-467. https://doi.org/10.1016/j.midw.2012.03.002

Hadi, S. P. I., Kuntjoro, T., Sumarni, S., Anwar, M. C., Widyawati, M. N., \& Pujiastuti, R. S. E. (2017). The Development of E-partograph Module as a Learning Platform for Midwifery Students: The ADDIE Model. Belitung Nursing Journal, 3(2), 148-156. https://doi.org/10.33546/bnj.77

Hasan, M. J., Hossain, M. S., Arafat, S. Y., Khan, A. S., Ahmed, Z., \& Shabnam, F. (2017). Comparative Analysis of Life Curve Mobile Application: an Easier Alternative to Existing Traditional Paper Partograph. 
IOSR-JMCA. https://doi.org/10.9790/0050-04015561

Underwood, H., Sterling, S. R., \& Bennett, J. K. (2012, October). Improving maternal labor monitoring in Kenya using digital pen technology: a user evaluation. In 2012 IEEE Global Humanitarian Technology Conference (pp. 282-287). IEEE. https://doi.org/10.1109/GHTC.2012.77

Schweers, J., Khalid, M., Underwood, H., Bishnoi, S., \& Chhugani, M. (2016). mLabour: Design and evaluation of a mobile partograph and labor ward management application. Procedia engineering, 159, 35-43. https://doi.org/10.1016/j.proeng.2016.08.061

Souza, J. P., Oladapo, O. T., Bohren, M. A., Mugerwa, K., Fawole, B., Moscovici, L., ... \& Tunçalp, Ö. (2015). The development of a simplified, effective, labour monitoring-to-action (SELMA) tool for better outcomes in labour difficulty (BOLD): study protocol. Reproductive health, 12(1), 49. https://doi.org/10.1186/s12978-015-0029-4

JNPK-KR. (2012). Normal Delivery Care. Jakarta: Indonesian Ministry of Health.

Vidyashri, K. C., \& Nagarathna, G. (2015). Documentation of the modified WHO partograph during labour in a South Indian tertiary care hospital. Journal of Evolution of Medical and Dental Sciences, 4(82), 14415-14422. https://doi.org/10.14260/jemds/2015/2050

Kitila, S. B., Gmariam, A., Molla, A., \& Nemera, G. (2014). Utilization of partograph during labour and birth outcomes at Jimma University. Journal of Pregnancy and Child Health, 1(101), 2. https://doi.org/10.4172/jpch.1000101.

Kwast, B. E. (1994). World Health Organization partograph in management of labour. World Health Organization Maternal Health and Safe Motherhood Programme. Lancet (London, England). https://doi.org/10.1016/S0140-6736(94)92528-3

Lavender, T., Hart, A., \& Smyth, R. M. (2013). Effect of partogram use on outcomes for women in spontaneous labour at term. Cochrane database of systematic reviews, (7). https://doi.org/10.1002/14651858.CD005461.pub4

Lew, V., \& Ghassemzadeh, S. (2018) SOAP Notes. StatPearls, 1. https://doi.org/10.1016/B978-0-323-07759-0.00020-1.

Mathibe-Neke, J. M., Lebeko, F. L., \& Motupa, B. (2013). The partograph: A labour management tool or a midwifery record?. International Journal of Nursing and Midwifery, 5(8), 145-153. https://doi.org/10.5897/IJNM2013.0115

Mandiwa, C., \& Zamawe, C. (2017). Documentation of the partograph in assessing the progress of labour by health care providers in Malawi's South-West zone. Reproductive health, 14(1), 134. https://doi.org/10.1186/s12978-017-0401-7

Markos, D., \& Bogale, D. (2015). Documentation status of the modified World Health Organization partograph in public health institutions of Bale zone, Ethiopia. Reproductive health, 12(1), 81. https://doi.org/10.1186/s12978-015-0074-z

Maureen D, et al. (2015). 'Documentation in labour among midwives in Madonna University Teaching Hospital elele, river state, Nigeria. Internastional Journal of Refroduction, Contraception, Obstetrics and Gynekology. https://doi.org/10.18203/2320-1770.ijrcog20150719

Mathews, J. E., Rajaratnam, A., George, A., \& Mathai, M. (2007). Comparison of two World Health Organization partographs. International Journal of Gynecology \& Obstetrics, 96(2), 147-150. https://doi.org/10.1016/j.ijgo.2006.08.016

Muslihatun, et al. (2013). Midwifery Documentation. Fitramaya: Yogyakarta.

Nugroho, B., Fitriasih, S. H., \& Widada, B. (2015). Medical Record Information System at Masaran I Sragen Public Health Center. Jurnal TIKomSiN. https://doi.org/10.30646/TIKOMSIN.V3I2.203.

Nurmiyati, T. (2011). Relationship between Knowledge Level and Midwife Compliance with Partograph Use in Madukara District and Pagentan Subdistrict, Banjarnegara Regency. Permata Medika Scientific Journal, 2(1). Retrieved from http://www.journal.stikes-bpm.ac.id/index.php/arsip/volume-2- no-1-juli-2013/17.

Nursing and Midwifery Council. (2010a). Standards for medicines management Record keeping. Standards for Medicine Management. Retrieved from https://www.nmc.org.uk/standards/standards-for-post-registration. 
Nursing and Midwifery Council. (2010b). Standards Record of keeping for proficiency nurse and midwife $\begin{array}{llll}\text { prescribers. } & \text { Education } & \text { And } & \text { Training. }\end{array}$ https://www.nmc.org.uk/standards/standards-for-post-registration

Okokon, I. B., Oku, A. O., Agan, T. U., Asibong, U. E., Essien, E. J., \& Monjok, E. (2014). An evaluation of the knowledge and utilization of the partogragh in primary, secondary, and tertiary care settings in Calabar, South-South Nigeria. International journal of family medicine, 2014. https://doi.org/10.1155/2014/105853

Ollerhead, E., \& Osrin, D. (2014). Barriers to and incentives for achieving partograph use in obstetric practice in low-and middle-income countries: A systematic review. BMC pregnancy and childbirth, 14(1), 281. https://doi.org/10.1186/1471-2393-14-281

Ontario, C. of M. of. (2013). Record Keeping Standard for Midwives, CMO Policy Suite.

Opoku, B. K., \& Nguah, S. B. (2015). Utilization of the modified WHO partograph in assessing the progress of labour in a metropolitan area in Ghana. Research Journal of Women's Health, 2(1), 2. https://doi.org/10.7243/2054-9865-2-2

Oxpord. (2013). Oxford Handbook of Midwifery. Kebidanan Oxford: From Midwives to Midwifes.

Perinatal Health Program. (2010). Perinatal Forms Guideline 4 A Guide For Completion of the British Columbia Labour Partogram (BCPHP 1583).

Pirie, S. (2011) Documentation and record keeping. Journal of perioperative practice. https://doi.org/10.1177/175045891102100103

Qureshi, Z. P., Sekadde-Kigondu, C., \& Mutiso, S. M. (2010). Rapid assessment of partograph utilisation in selected maternity units in Kenya. East African medical journal, 87(6), 235-241. https://doi.org/10.4314/eamj.v87i6.63081

Ramdhani, A. et al. (2015). Development of Expert Systems for Diagnosis of Web-Based Hepatitis Using Certainty Factor. JTsiskom.

Sama, C. B., Takah, N. F., Danwe, V. K., Melo, U. F., Dingana, T. N., \& Angwafo III, F. F. (2017). Knowledge and utilization of the partograph: A cross-sectional survey among obstetric care providers in urban referral public health institutions in northwest and southwest Cameroon. PloS one, 12(2), e0172860. https://doi.org/10.1371/journal.pone.0172860

Seo, J. H., Kong, H. H., Im, S. J., Roh, H., Kim, D. K., Bae, H. O., \& Oh, Y. R. (2016). A pilot study on the evaluation of medical student documentation: assessment of SOAP notes. Korean journal of medical education, 28(2), 237. https://doi.org/10.3946/kjme.2016.26

Sharma, R., Deka, G., \& Das, G. C. (2015). The Paperless partograph - The new user-friendly and simpler tool for monitoring labour. IOSR Journal of Dental and Medical Sciences. https://doi: 10.9790/0853-141193943.

Sinaga, R. N. (2016). Analysis and Design of a Medical Record Information System at the Akper Clinic in the Middle/ Srivijaya White Garuda. Journal of Information Systems Management, 1(1), 2540-8011.

Sinha, D., Shrivastava, S., \& Shrivastava, S. (2016). Management of Labour in Primigravida with Who Modified Partograph. Scholars Journal of Applied Medical Sciences, 4, 3457-3461. https://doi: 10.21276/sjams.2016.4.9.59

Sovia, R., \& Febio, J. (2011). Build e-library applications using html, php script, and mysql database. Journal of Information and Education Technology, 3(1), 2011.Retrieved from http://ejournal.stikom-db.ac.id/index.php/processor/article/view/28

Sudarti, F. (2011). Textbook for Midwifery Documentation. Nuha Medika: Jakarta.

Sugiyono. (2014). Educational Research Methods Quantitative, Qualitative Approach and $R \& D$. Bandung: Alfabeta.

Sundari, J. (2016). Web-Based Puskesmas Service Information System. Indonesian Journal on Software Engineering. IJSE - Indonesian Journal on Software Engineering, 2(1).

Susilowati, \& Sulistiyaningsih, S. H. (2011). Analysis of Factors Associated with Making Partographs by Midwives at Dukuhseti Health Center and Tayu Ii Health Center, Pati Regency. Midwifery and Health Journal, 3(2). 
Tayade, S., \& Jadhao, P. (2012). The impact of use of modified WHO partograph on maternal and perinatal outcome. International Journal of Biomedical and Advance Research, 3(4), 256-262. https://doi.org/10.7439/ijbar.v3i4.398

Toemandoek, J. P., Wagey, F., \& Loho, M. (2015). Knowledge and Attitudes of Midwives Regarding the Use of Partographies in Childbirth at Poned Public Health Center, Manado City. Journal e-Clinic (eCl), 3(2). Retrieved from https://ejournal.unsrat.ac.id/index.php/eclinic/article/view/9344/8921

Varney, H. (2008). Varney's Midwifery. EGC : Jakarta.

Widyaningsih, P., \& Astutingsih, A. (2016). Web-Based Expert System Application for Consultation on Pregnancy Problems Using Forward Chaining and Production Rule. INITI MEDICAL APPLICATION Journal, IMAGE MEDIKA SURAKARTA.

Wildan dan Hidayat. (2009). Midwifery Documentation. Salemba Medika: Jakarta.

World Health Organization [WHO]. (2011). WHO recommendations for Induction of labour. World Health Organization. https://doi:org.10.1016/0140-6736(93)92727-B.

World Health Organization [WHO]. (2014). WHO recommendations for augmentation of labour. World Health Organization. https://doi.org/10.1016/0140-6736(93)92727-B.

Yisma, E., Dessalegn, B., Astatkie, A., \& Fesseha, N. (2013a). Completion of the modified World Health Organization (WHO) partograph during labour in public health institutions of Addis Ababa, Ethiopia. Reproductive health, 10(1), 23. https://doi.org/10.1186/1742-4755-10-23

Yisma, E., Dessalegn, B., Astatkie, A., \& Fesseha, N. (2013b). Knowledge and utilization of partograph among obstetric care givers in public health institutions of Addis Ababa, Ethiopia. BMC pregnancy and childbirth, 13(1), 17. https://doi.org/10.1186/1471-2393-13-17

Yulianti, N. T., Ahmad, M., Syarif, S., Budu, \& Sunarno, I. (2017). Comparison Partograph Based on Computer System and Partograph Convensional on Monitoring Record Report Progress of Labor. International Journal of Chem Tech Research, 11(05). 363-368. https://doi.org/10.20902/IJCTR.2018.110540

\section{Copyrights}

Copyright for this article is retained by the author(s), with first publication rights granted to the journal.

This is an open-access article distributed under the terms and conditions of the Creative Commons Attribution license (http://creativecommons.org/licenses/by/4.0/). 